\title{
Pengembangan Perangkat Pembelajaran Bahasa Inggris Berbasis Lingkungan "Leksikon Dalam Bahasa Mbojo" Untuk Mengembangkan Kreativitas Mahasiswa
}

\author{
Indah Afrianti ${ }^{1}$, Nur Wahyuni ${ }^{2}$ \\ STKIP Yapis Dompu, Nusa Tenggara Barat, Indonesia \\ E-mail: indahgracilaria@gmail.com
}

\begin{tabular}{|c|c|}
\hline Article Info & Abstract \\
\hline $\begin{array}{l}\text { Article History } \\
\text { Received: } 2021-07-12 \\
\text { Revised: } 2021-08-15 \\
\text { Published: } 2021-10-15\end{array}$ & $\begin{array}{l}\text { This research is a development research using a 4-D model which consists of several } \\
\text { steps, namely define, design, develop and disseminate. The learning model used in this } \\
\text { study is environment-based learning with the following stages: determining basic } \\
\text { questions, designing project plans, developing schedules, monitoring project progress, } \\
\text { testing learning processes and outcomes, and evaluating experiences. Based on the } \\
\text { results of data validation, environmental-based English learning devices (textbooks) } \\
\text { were declared feasible to be used in English lectures because they were prepared in } \\
\text { accordance with writing standards for teaching materials, the material was presented } \\
\text { well, the language used was easy to understand, the questions given could be done by } \\
\text { students. Student. Textbooks are also effective in increasing the achievement of } \\
\text { student learning outcomes because they are actively involved in finding material, } \\
\text { finding relationships between materials, being able to apply their knowledge so that } \\
\text { students will be able to construct knowledge gained from their experiences and can } \\
\text { improve and develop student creativity. }\end{array}$ \\
\hline Artikel Info & Abst \\
\hline $\begin{array}{l}\text { Sejarah Artikel } \\
\text { Diterima: } 2021-07-12 \\
\text { Direvisi: 2021-08-15 } \\
\text { Dipublikasi: } 2021-10-15\end{array}$ & $\begin{array}{l}\text { Penelitian ini adalah penelitian pengembangan dengan menggunakan model 4-D yang } \\
\text { terdiri dari beberapa langkah, yakni define, desain, develop and diseminasi. Model } \\
\text { pembelajaran yang digunakan dalam penelitian ini yaitu pembelajaran berbasis } \\
\text { lingkungan dengan tahapan: menentukan pertanyaan mendasar, mendesain } \\
\text { perencanaan projek, menyusun jadwal, monitoring kemajuan projek, menguji proses } \\
\text { dan hasil belajar, evaluasi pengalaman. hasil validasi data dalam penelitian ini } \\
\text { diantaranya: perangkat pembelajaran (buku ajar) bahasa inggris berbasis lingkungan } \\
\text { dinyatakan layak untuk digunakan pada perkuliahan bahasa inggris karena disusun } \\
\text { sesuai dengan standar penulisan bahan ajar, materi yang disajikan dengan baik, bahasa } \\
\text { yang digunakan mudah untuk dipahami, soal yang diberikan dapat dikerjakan oleh } \\
\text { mahasiswa. Buku ajar juga efektif dalam meningkatkan pencapaian hasil belajar } \\
\text { mahasiswa karena terlibat secara aktif dalam menemukan materi, menemukan } \\
\text { hubungan antara materi, mampu menerapkan pengetahuannya sehingga mahasiswa } \\
\text { akan mampu mengkonstruksi pengetahuan yang diperoleh dari pengalamannya dan } \\
\text { dapat meningkatkan dan mengembangkan kreativitas mahasiswa. }\end{array}$ \\
\hline
\end{tabular}

\section{PENDAHULUAN}

Tenaga pendidik berkewajiban untuk mengembangkan perangkat pembelajaran untuk mengembangkan kopetensinnya dalam dunia pendidikan di perguruan tinggi, termasuk dosen dilingkup STKIP Yapis Dompu, hal tersebut sesuai dengan Peraturan Pemerintah No. 19 tahun 2005 yang menyatakan bahwa setiap dosen pada satuan pendidikan berkewajiban menyusun perangkat pembelajaran yang kreatif dan inovatif, tujuanya ialah agar pembelajaran berlangsung secara interaktif, inspiratif, menyenangkan, menantang, memotivasi mahasiswa untuk berpartisipasi aktif, serta memberikan ruang yang cukup bagi prakarsa, kreativitas, dan kemandirian sesuai dengan bakat, minat, dan perkembangan fisik serta psikologis mahasiswa, Pengembangan keterampilan dan pengetahuan mahasiswa disesuaikan dengan lingkungan terdekatnya, baik lingkungan mahasiswa berupa pengalaman dan pengetahuan linguistik yang dimilikinya maupun diluar diri mahasiswa, seperti keluarga, teman, lingkungan alam dll. Potensi budaya kabupaten Dompu, Nusa Tenggara Barat (Afrianti, 2017).

Hasil observasi dan wawancara awal pada mahasiswa Program Studi Pendidikan Jamani Kesehatan dan Rekreasi (PJKR) STKIP Yapis Dompu pada mata kuliah Bahasa Inggris menunjukan bahwa para mahasiswa masih kesulitan dalam penguasaan kosakata bahasa Inggris dan ada beberapa faktor yang menyeba- 
bkan mata kuliah bahasa Inggris dinilai sulit karena materi yang diberikan bersifat umum dan tidak berkaitan dengan aspek keolahragaan. Jadi suasana belajar bahasa Inggris kurang menarik dan menye-nangkan. mahasiswa tersebut merasa takut dalam menggunakan Bahasa Inggris, karena mahasiswa merasa bingung dalam pemilihan kata untuk berkomunikasi, mahasiswa jarang mengaplikasi-kannya dalam kehidupan sehari-hari, mahasiswa merasa tidak percaya diri menggunakan bahasa Inggris, karena tidak memiliki banyak koleksi kosakata, mahasiswa merasa takut apabila membuat kesalahan dalam menggunakan kalimat bahasa Inggris. Melihat permasalahan yang muncul pada proses pembelajaran pada mata kuliah bahasa Inggris di Program Studi Pendidikan Jasmani Kesehatan dan Rekreasi (PJKR), khususnya pengetahuan tentang leksikon/ kosakata olahraga, maka dalam penelitian ini peneliti menggunakan pembe-lajaran berbasis lingkungan.

Bahasa Inggris adalah bahasa asing pertama sebagai mata kuliah dasar umum pada tingkat Universitas/ Sekolah tinggi di Indonesia. Perkembangan perencanaan pembelajaran mengikuti perkembangan kebijakan pendidikan di Indonesia dan dituangkan dalam kurikulum merdeka belajar-kampus merdeka (MBKM). Tujuan pembelajaran bahasa Inggris yang tertuang dalam (MBKM) adalah memiliki kompetensi komunikasi meliputi kompetensi wacana, kompetensi sosial budaya, kompetensi aksional, kompetensi kebahasaan, dan kompetensi strategi. Kompetensi yang direncanakan ini merupakan adaptasi dari Celce-Murcia dkk. (1995). Kompetensi yang ingin dicapai meliputi kompetensi sikap, pengetahuan, dan keterampilan (character, knowledge, and skills), sehingga fitur-fitur teks mengandung usur-unsur fungsi sosial, struktur teks, dan kebahasaan sebagai satu kesatuan pembelajaran bahasa yang utuh. (dalam Endah Nur Tjendani Dkk, 2020).

Dari tujuan pembelajaran bahasa Inggris di atas, tampak jelas bahwa bahasa dipelajari untuk tujuan pencapaian kompetensi komunikasi aktif, baik tulis mau pun ucap. Bahasa juga tidak bisa dipelajari secara terpisah dari kegunaannya dan mandiri, tetapi belajar bersama-sama dengan digunakan berkomunikasi dengan lingkungannya, baik lingkungan alam, sosial, maupun budaya untuk mencapai satu kesatuan kompetensi yang utuh pada diri mahasiswa. Hal ini sesuai dengan spirit ekolinguistik, yaitu belajar merupakan tindakan nyata berupa aktivitas bahasa dan produksi bahasa (van Lier,
2004; Halliday, 2014). Aktivitas bahasa berupa proses yang dilakukan untukmenghasilkan produksi bahasa, sehingga untuk mendapatkan kompetensi komunikasi yang utuh diperlukan sistem relasi antara mahasiswa dan gagasannya, mahasiswa dan lingkungannya, mahasiswa dan mahasiswa, dan mahasiswa dan dosen.

Secara praktik, kontekstualisasi pembelajaran bahasa Inggris sesuai dengan kondisi lingkungan dan mahasiswa (Kemendiknas, 2016). Kondisi lingkungan adalah sistem lingkungan alam, sosial, dan budaya sebagai ideologi bangsa tempat mahasiswa tinggal. Indonesia yang memiliki sekitar 17.491 pulau (data tahun 2019), memiliki lima pulau terbesar, melipiti Papua, Kalimantan, Sumatra, Sulawesi, dan Jawa (okezone.com) dengan sistem sumber daya alam yang berbeda-beda, seperti beras paling banyak dihasilkan di pulau Jawa dan Sumatra, jagung dari NTT dan NTB, rempah-rempah dari pulau Sulawasi, dan sebagainya. Perbedaan ini merupakan kekayaan hayati yang perlu dilestarikan ekosistemnya. Salah satu upaya pelestarian melalui pembelajaran bahasa dengan konteks keragaman hayati secara biologis asli pada setiap pulau tempat mahasiswa tinggal. mahasiswa yang tinggal di Papua belajar keragaman flora dan fauna dan manfaatnya di wilayah tersebut, demikian juga dengan pulaupulau yang lain. (dalam Endah Nur Tjendani,2020).

Pembelajaran berbasis lingkungan merupakan suatu pembelajaran yang menggunakan objek belajar (mahasiswa) sebagai pengalaman nyata, mengamati secara langsung, memperoleh data-data akurat dan mahasiswa dapat belajar secara mandiri ataupun berkelompok, Pembelajaran berbasis lingkungan mengarah pada pembelajaran yang memanfaatkan lingkungan sebagai sumber belajar. Pemahaman mahasiswa terhadap materi tentang lingkungan sekitar yang diberikan dapat bertahan lebih lama, karena mahasiswa dapat mengingatya secara terusmenerus, Pembelajaran berbasis lingkungan dalam meningkatkan pengetahuan tentang leksikon olahraga dilakukan untuk melibatkan mahasiswa secara langsung dalam pembelajaran, sehingga mahasiswa memahami hasil belajarnya sesuai fakta dan pengalaman yang dialami, bukan sekedar dari dosennya. Pada dasarnya pembelajaran berbasis lingkungan lebih menekankan pada proses belajar sambil melakukan sesuatu (learning by doing).

Jelas bahwa belajar bahasa tidak hanya berarti menyelidiki struktur bahasa tetapi juga berarti 
mengetahui bahwa bahasa tidak dapat dipisahkan dari lingkungan biologis/alam, sosial, dan ideologis/budaya di mana bahasa digunakan untuk memperoleh makna yang utuh. Belajar bahasa adalah proses semiotik dalam konteks budaya dan teks tertentu. Dalam pembelajaran bahasa proses semiotik disebut juga sebagai linguistik kognitif (Janda, 2010), karena belajar bahasa berarti menerjemahkan, memahami, menafsirkan, memahami dan menggunakan katakata. Dan simbol budaya tanpa dipengaruhi oleh seberapa cerdas seorang pembelajar. Meskipun bahasa yang dipelajari adalah bahasa asing, namun proses pembelajaran tidak mengubah atau memisahkan hubungan mahasiswa dengan lingkungan sekitarnya (van Lier, 2004). Konteks budaya dapat ditemukan di lingkungan sekitar, tempat tinggal, sekolah, pasar, kantor dan di mana-mana. Teks yang digunakan untuk mempelajari bahasa inggris mengandung unsur budaya berupa bentuk-bentuk kebahasaan yang akan diajarkan seperti dalam mengenalkan leksikon dan tata bahasa dari bahasa sasaran. Dalam hal ini, leksikon mencakup setiap item leksikal yang digunakan untuk menunjukkan pengetahuan baru dalam bahasa sasaran yang setara dengan budaya lokal. Tata bahasa dalam hal ini berarti memperkenalkan unsur-unsur gramatikal seperti fonem, morfem, kata, frasa, klausa, dan wacana yang mengandung baik budaya lokal maupun budaya sasaran. Oleh karena itu, penting untuk mengetahui model pendekatan ekolinguistik untuk mengembangkan silabus berbasis fenomena sosial, budaya dan kebahasaan. (dalam Endah Nur Tjendani, 2019.

Berdasarkan latar belakang di atas, maka ditentukan tujuan dari penelitian ini yaitu: untuk menghasilkan perangkat pembelajaran bahasa Inggris berbasis lingkungan "Leksikon dalam Bahasa Mbojo" untuk mengembangkan kreativitas mahasiswa yang berkualitas baik.

\section{METODE PENELITIAN}

Metode yang digunakan dalam penelitian ini adalah penelitian pengembangan. Pada metode penelitian pengembangan terdapat beberapa jenis model. Model yang digunakan adalah pengembangan model 4-D. Model pengembangan 4-D (Four D) merupakan model pengembangan perangkat pembelajaran, model ini dikembangkan oleh S. Thiagarajan, Dorothy S. Semmel, dan Melvyn I. Semmel (1974: 5) (dalam asmedy 2018) Model pengembangan 4D terdiri atas 4 tahap utama yaitu: Define (Pendefinisian), Design (Perancangan) Develop (Pengembangan) dan
Disseminate (Penyebaran). Metode dan model ini dipilih karena bertujuan untuk menghasilkan produk berupa buku ajar. Produk yang dikembangkan kemudian diuji kelayakannya dengan validitas dan uji coba produk untuk mengetahui sejauh mana pengembangan kreatifitas mahasiswa dan hasil belajar mahasiswa menggunakan pembelajaran berbasis lingkungan pada mata kuliah bahasa inggris.

Penelitian ini dilaksanakan pada mahasiswa Program Studi Pendidikan Jasmani dan Rekreasi STKIP Yapis Dompu, Semester II dengan jumlah 59 orang mahasiswa tahun pembelajaran 2020/2021, prosedur pengembangan yang digunakan adalah model Thiagarajan modifikasi dalam (Asmedy, 2018), sedangkan instrument yang digunakan dalam penelitian ini diantaranya: Lembar Validasi Perangkat Pembelajaran, Whorksheet, Lembar observasi kemampuan dosen mengelola pembelajaran, Angket respon, dan Tes Hasil Belajar, Analisis Data hasil Validasi dilakukan dengan menentukan Data hasil penilaian dari validator dianalisis berdasarkan pada rata-rata skor:

$$
\begin{aligned}
& 1,00 \leq \text { Rata-rata } \leq 1,50 \text { sangat tidak baik } \\
& 1,50<\text { Rata-rata } \leq 2,50 \text { tidak baik } \\
& 2,50<\text { Rata-rata } \leq 3,50 \text { baik } \\
& 3,50<\text { Rata-rata } \leq 4,00 \text { sangat baik }
\end{aligned}
$$

Perangkat pembelajaran dikatakan valid jika untuk setiap perangkat pembelajaran berada pada kategori rata-rata lebih dari 25. Dengan demikian, hasil analisis data yang tidak memenuhi salah satu kategori baik atau sangat baik maka akan dijadikan bahan pertimbangan untuk merevisi perangkat pembelajaran.

\section{Analisis Data Uji Coba}

1) Analisis data kemampuan dosen mengelola pembelajaran

Data tentang kemampuan dosen mengelola pembelajaran dianalisis dengan menggunakan statistik deskriptif yaitu dengan skor rata-rata sebagai berikut:

$1,00 \leq$ Rata-rata $\leq 1,50$ sangat tidak baik

$1,50<$ Rata-rata $\leq 2,50$ tidak baik

$2,50<$ Rata-rata $\leq 3,50$ baik

$3,50<$ Rata-rata $\leq 4,00$ sangat baik

Kemampuan dosen mengelola pembelajaran dikatakan efektif jika rata-rata skor dari setiap aspek yang dinilai untuk setiap RPS berada pada kategori minimal baik.

2) Data Respon Mahasiswa

Persentase dari setiap respon mahasiswa dihitung dengan rumus: 
Iumlah respon positif untuk setiap aspek Jumlah seluruh siswa

Respon mahasiswa dikategorikan positif jika mahasiswa memilih pernyataan "setuju/ senang", atau "sangat setuju/ sangat senang" untuk aspek positif, dan memilih pernyataan "tidak setuju/ tidak senang" atau "sangat tidak setuju/ sangat tidak senang" untuk aspek negatif yang tertera pada angket dengan persentase $\geq 70 \%$.

3) Analisis Data Tes kreativitas

Data yang diperoleh dari TK selanjutnya diolah untuk menentukan validitas butir tes, sensitivitas butir tes, dan reliabilitas tes, Analisis data tes hasil belajar secara deskriptif bertujuan untuk mendeskripsikan hasil tes hasil belajar dan data yang dianalisis adalah data post-test.

\section{HASIL DAN PEMBAHASAN}

Berdasarkan hasil uji/validasi pakar, produk bahan ajar Bahasa Inggris berbasis lingkungan yang dihasilkan di dalam penelitian ini dinilai telah memenuhi seluruh aspek teoritis pengembangan perangkat pembelajaran bahasa inggris berbasis lingkungan "leksikon bahasa mbojo" untuk mengembangkan kreativitas mahasiswa.

1) Analisis Data Validasi

Data hasil penilaian dari validator dianalisis berdasarkan pada rata-rata skor:

$1,00 \leq$ Rata-rata $\leq 1,50$ sangat tidak baik

$1,50<$ Rata-rata $\leq 2,50$ tidak baik

$2,50<$ Rata-rata $\leq 3,50$ baik

$3,50<$ Rata-rata $\leq 4,00$ sangat baik

Tabel 1. Hasil Validasi Perangkat Pembelajaran Oleh Dua (2) Ahli (Validator)

\begin{tabular}{llcccc}
\hline \multirow{2}{*}{ No } & $\begin{array}{l}\text { Jenis } \\
\text { Perangkat }\end{array}$ & \multicolumn{2}{c}{ Hasil Validasi } & \multirow{2}{*}{$\begin{array}{c}\text { Skor } \\
\text { rerata }\end{array}$} & $\begin{array}{c}\text { Katego } \\
\text { ri }\end{array}$ \\
\cline { 2 - 4 } & V1 & V2 & & \\
\hline 1 & RPS & 3.50 & 3.10 & 3.30 & Baik \\
\hline 2 & Buku Ajar & 3.10 & 3.20 & 3.15 & Baik \\
\hline 3 & Worsheet & 3.20 & 3.00 & 3.10 & Baik \\
\hline \multirow{2}{*}{4} & $\begin{array}{l}\text { Soal Tes } \\
\text { Kreatif }\end{array}$ & 3.40 & 3.10 & 3.25 & Baik \\
\hline \multicolumn{2}{c}{ Rata-rata } & $\mathbf{3 . 3 0}$ & 3.082 & 3.186 & Baik \\
\hline
\end{tabular}

Berdasarkan table di atas, dapat diketahui bahwa perangkat pembelajaran ini divalidasi oleh dua (2) orang validator ahli yakni yang pertama bergelar S.Pd.,M.Pd dengan keilmuan Pendidikan bahasa inggris dan validator yang kedua S.Pd., M.A dengan keilmuan pendidikan bahasa inggris. Adapun perangkat yang divalidasi berupa RPS dengan nilai rerata 3.30 dengan kategori baik.Selanjutnya untuk Buku ajar memiliki nilai rerata 3.15 dengan kategori Baik, sedangkan untuk Worksheet memiliki nilai rerata 3.10 juga berkategori baik dan soal tes kreatif dengan rerata 3.25 berada dalam kategori baik.

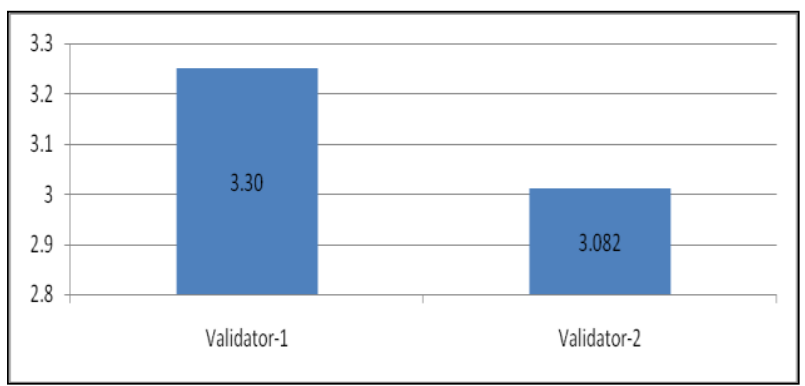

Gambar 1. Diagram rerata hasil validasi perangkat pembelajaran

Berdasarkan diagram rerata hasil validasi perangkat di atas dapat diketahui bahwa hasil keseluruhan perangkat pembelajaran yang divalidasi oleh validator satu (1) dengan nilai rerata sebesar 3.30 sedangkan hasil validasi perangkat secara keseluruhan oleh validator dua (2) dengan rerata sebesar 3.082.

2) Analisis data uji coba

Pada tahap ini, diberikan angket berupa pernyataan respon kepada mahasiswa bertujuan untuk mengetahui respon mahasiswa terhadap pembelajaran berbasis lingkungan yang telah dilakukan selama proses pembelajaran sangat menarik dan menyenangkan. Berikut dipaparkan hasil respon pernyataan mahasiswa.

Tabel 2. Kuesioner Respon Pernyataan Mahasiswa

\begin{tabular}{|c|c|c|c|c|}
\hline No & Pernyataan & Pilihan & $\begin{array}{l}\text { Jumlah } \\
\text { Siswa }\end{array}$ & $\begin{array}{l}\text { Persent } \\
\text { ase }(\%)\end{array}$ \\
\hline \multirow{4}{*}{1} & \multirow{4}{*}{$\begin{array}{l}\text { Pembelajaran } \\
\text { berbasis } \\
\text { lingkungan lebih } \\
\text { bermanfaat } \\
\text { untuk belajar } \\
\text { Bahasa Inggris. }\end{array}$} & $\begin{array}{l}\text { Sangat } \\
\text { setuju }\end{array}$ & 30 & 50.84 \\
\hline & & Setuju & 20 & 33.89 \\
\hline & & $\begin{array}{c}\text { Kurang } \\
\text { setuju }\end{array}$ & 5 & 8.47 \\
\hline & & $\begin{array}{c}\text { Tidak } \\
\text { setuju }\end{array}$ & 4 & 6.77 \\
\hline \multirow{4}{*}{2} & \multirow{4}{*}{$\begin{array}{l}\text { Menurut saya, } \\
\text { pembelajaran } \\
\text { berbasis } \\
\text { lingkungan } \\
\text { dalam } \\
\text { pembelajaran } \\
\text { Bahasa Inggris }\end{array}$} & $\begin{array}{l}\text { Sangat } \\
\text { setuju }\end{array}$ & 25 & 42.37 \\
\hline & & Setuju & 30 & 50.84 \\
\hline & & $\begin{array}{c}\text { Kurang } \\
\text { setuju }\end{array}$ & 2 & 3.38 \\
\hline & & $\begin{array}{l}\text { Tidak } \\
\text { setuju }\end{array}$ & 2 & 3.38 \\
\hline
\end{tabular}




\begin{tabular}{|c|c|c|c|c|}
\hline & menjemukan & & & \\
\hline \multirow{4}{*}{3} & \multirow{4}{*}{$\begin{array}{l}\text { Belajar Bahasa } \\
\text { Inggris dengan } \\
\text { menggunakan } \\
\text { pembelajaran } \\
\text { berbasis } \\
\text { lingkungan } \\
\text { membuat saya } \\
\text { lebih terampil. }\end{array}$} & $\begin{array}{l}\text { Sangat } \\
\text { setuju }\end{array}$ & 27 & 45.76 \\
\hline & & Setuju & 29 & 49.15 \\
\hline & & $\begin{array}{c}\text { Kurang } \\
\text { setuju }\end{array}$ & 1 & 1.69 \\
\hline & & $\begin{array}{l}\text { Tidak } \\
\text { setuju }\end{array}$ & 2 & 3.38 \\
\hline \multirow{4}{*}{4} & \multirow{4}{*}{$\begin{array}{l}\text { Pembelajaran } \\
\text { berbasis } \\
\text { lingkungan } \\
\text { mempersulit } \\
\text { saya dalam } \\
\text { menyelesaikan } \\
\text { persoalan dalam } \\
\text { pelajaran Bahasa } \\
\text { Inggris. }\end{array}$} & $\begin{array}{l}\text { Sangat } \\
\text { setuju }\end{array}$ & 30 & 50.84 \\
\hline & & Setuju & 25 & 42.37 \\
\hline & & $\begin{array}{c}\text { Kurang } \\
\text { setuju }\end{array}$ & 3 & 5.08 \\
\hline & & $\begin{array}{l}\text { Tidak } \\
\text { setuju }\end{array}$ & 1 & 1.69 \\
\hline \multirow{4}{*}{5} & \multirow{4}{*}{$\begin{array}{l}\text { Belajar Bahasa } \\
\text { Inggris } \\
\text { menggunakan } \\
\text { pembelajaran } \\
\text { membuat saya } \\
\text { lebih memahami } \\
\text { materi. }\end{array}$} & $\begin{array}{l}\text { Sangat } \\
\text { setuju }\end{array}$ & 10 & 16.94 \\
\hline & & Setuju & 40 & 67.79 \\
\hline & & $\begin{array}{c}\begin{array}{c}\text { Kurang } \\
\text { setuju }\end{array} \\
\end{array}$ & 5 & 8.47 \\
\hline & & $\begin{array}{l}\text { Tidak } \\
\text { setuju }\end{array}$ & 4 & 6.77 \\
\hline \multirow{4}{*}{6} & \multirow{4}{*}{$\begin{array}{l}\text { Belajar Bahasa } \\
\text { Inggris } \\
\text { menggunakan } \\
\text { pembelajaran } \\
\text { berbasis } \\
\text { lingkungan saya } \\
\text { merasa lebih } \\
\text { termotivasi. }\end{array}$} & $\begin{array}{l}\text { Sangat } \\
\text { setuju }\end{array}$ & 25 & 42.37 \\
\hline & & Setuju & 25 & 42.37 \\
\hline & & $\begin{array}{c}\text { Kurang } \\
\text { setuju }\end{array}$ & 6 & 10.16 \\
\hline & & $\begin{array}{l}\text { Tidak } \\
\text { setuju }\end{array}$ & 3 & 5.08 \\
\hline \multirow{4}{*}{7} & \multirow{4}{*}{$\begin{array}{l}\text { Belajar Bahasa } \\
\text { Inggris dengan } \\
\text { menggunakan } \\
\text { pembelajaran } \\
\text { berbasis } \\
\text { lingkungan } \\
\text { melatih saya } \\
\text { untuk bisa } \\
\text { mengemukakan } \\
\text { pendapat. }\end{array}$} & $\begin{array}{l}\text { Sangat } \\
\text { setuju }\end{array}$ & 20 & 33.89 \\
\hline & & Setuju & 25 & 42.37 \\
\hline & & $\begin{array}{c}\text { Kurang } \\
\text { setuju }\end{array}$ & 9 & 15.25 \\
\hline & & $\begin{array}{l}\text { Tidak } \\
\text { setuju }\end{array}$ & 5 & 8.47 \\
\hline \multirow{4}{*}{8} & \multirow{4}{*}{$\begin{array}{l}\text { Belajar Bahasa } \\
\text { Inggris } \\
\text { menggunakan } \\
\text { pembelajaran } \\
\text { berbasis } \\
\text { lingkungan } \\
\text { membuat saya } \\
\text { lebih aktif dalam } \\
\text { belajar. }\end{array}$} & $\begin{array}{l}\text { Sangat } \\
\text { setuju }\end{array}$ & 28 & 13.55 \\
\hline & & Setuju & 20 & 33.89 \\
\hline & & $\begin{array}{c}\text { Kurang } \\
\text { setuju }\end{array}$ & 7 & 11.86 \\
\hline & & $\begin{array}{l}\text { Tidak } \\
\text { setuju }\end{array}$ & 4 & 6.77 \\
\hline \multirow{4}{*}{9} & \multirow{4}{*}{$\begin{array}{l}\text { Belajar Bahasa } \\
\text { Inggris } \\
\text { menggunakan } \\
\text { pembelajaran } \\
\text { berbasis } \\
\text { lingkungan } \\
\text { membuat materi } \\
\text { mudah diingat. }\end{array}$} & $\begin{array}{l}\text { Sangat } \\
\text { setuju }\end{array}$ & 30 & 50.84 \\
\hline & & Setuju & 20 & 33.89 \\
\hline & & $\begin{array}{c}\text { Kurang } \\
\text { setuju }\end{array}$ & 7 & 11.86 \\
\hline & & $\begin{array}{l}\text { Tidak } \\
\text { setuju }\end{array}$ & 2 & 3.38 \\
\hline \multirow{4}{*}{10} & \multirow{4}{*}{$\begin{array}{l}\text { Pembelajaran } \\
\text { berbasis } \\
\text { lingkungan } \\
\text { membuat } \\
\text { pelajaran Bahasa } \\
\text { Inggris lebih } \\
\text { menarik untuk }\end{array}$} & $\begin{array}{l}\text { Sangat } \\
\text { setuju }\end{array}$ & 25 & 42.37 \\
\hline & & Setuju & 25 & 42.37 \\
\hline & & $\begin{array}{c}\text { Kurang } \\
\text { setuju }\end{array}$ & 8 & 13.55 \\
\hline & & $\begin{array}{c}\text { Tidak } \\
\text { setuju }\end{array}$ & 1 & 1.69 \\
\hline
\end{tabular}

\begin{tabular}{|c|c|c|c|c|}
\hline & dipelajari. & & & \\
\hline \multirow{4}{*}{11} & \multirow{4}{*}{$\begin{array}{l}\text { Saya merasa rugi } \\
\text { belajar Bahasa } \\
\text { Inggris } \\
\text { menggunakan } \\
\text { pembelajaran } \\
\text { berbasis } \\
\text { lingkungan. }\end{array}$} & $\begin{array}{l}\text { Sangat } \\
\text { setuju }\end{array}$ & 35 & 59.32 \\
\hline & & Setuju & 20 & 33.89 \\
\hline & & $\begin{array}{c}\text { Kurang } \\
\text { setuju }\end{array}$ & 2 & 3.38 \\
\hline & & $\begin{array}{c}\text { Tidak } \\
\text { setuju } \\
\end{array}$ & 2 & 3.38 \\
\hline \multirow{4}{*}{12} & \multirow{4}{*}{$\begin{array}{l}\text { Pembelajaran } \\
\text { berbasis } \\
\text { lingkungan } \\
\text { mendorong saya } \\
\text { untuk } \\
\text { menemukan ide- } \\
\text { ide baru. }\end{array}$} & $\begin{array}{l}\begin{array}{l}\text { Sangat } \\
\text { setuju }\end{array} \\
\end{array}$ & 21 & 35.59 \\
\hline & & Setuju & 30 & 50.84 \\
\hline & & $\begin{array}{c}\begin{array}{c}\text { Kurang } \\
\text { setuju }\end{array} \\
\end{array}$ & 3 & 5.08 \\
\hline & & $\begin{array}{l}\text { Tidak } \\
\text { setuju } \\
\end{array}$ & 5 & 8.47 \\
\hline \multirow{4}{*}{13} & \multirow{4}{*}{$\begin{array}{l}\text { Pembelajaran } \\
\text { berbasis } \\
\text { lingkungan } \\
\text { kurang } \\
\text { bermanfaat } \\
\text { untuk belajar } \\
\text { Bahasa Inggris. }\end{array}$} & $\begin{array}{l}\text { Sangat } \\
\text { setuju }\end{array}$ & 40 & 67.79 \\
\hline & & Setuju & 15 & 25.42 \\
\hline & & $\begin{array}{c}\text { Kurang } \\
\text { setuju }\end{array}$ & 3 & 5.08 \\
\hline & & $\begin{array}{c}\text { Tidak } \\
\text { setuju }\end{array}$ & 1 & 1.69 \\
\hline \multirow{4}{*}{14} & \multirow{4}{*}{$\begin{array}{l}\text { Saya kurang } \\
\text { mengerti materi, } \\
\text { saat belajar } \\
\text { Bahasa Inggris } \\
\text { menggunakan } \\
\text { pembelajaran } \\
\text { berbasis } \\
\text { lingkungan. } \\
\end{array}$} & $\begin{array}{l}\begin{array}{l}\text { Sangat } \\
\text { setuju }\end{array} \\
\end{array}$ & 15 & 25.42 \\
\hline & & Setuju & 40 & 67.79 \\
\hline & & $\begin{array}{c}\text { Kurang } \\
\text { setuju }\end{array}$ & 1 & 1.69 \\
\hline & & $\begin{array}{l}\text { Tidak } \\
\text { setuju }\end{array}$ & 3 & 5.08 \\
\hline \multirow{4}{*}{15} & \multirow{4}{*}{$\begin{array}{l}\text { Pembelajaran } \\
\text { berbasis } \\
\text { lingkungan } \\
\text { kurang } \\
\text { bermanfaat } \\
\text { untuk belajar } \\
\text { Bahasa Inggris. }\end{array}$} & $\begin{array}{l}\begin{array}{l}\text { Sangat } \\
\text { setuju }\end{array} \\
\end{array}$ & 20 & 33.89 \\
\hline & & Setuju & 20 & 33.89 \\
\hline & & $\begin{array}{c}\begin{array}{c}\text { Kurang } \\
\text { setuju }\end{array} \\
\end{array}$ & 10 & 16.94 \\
\hline & & $\begin{array}{l}\text { Tidak } \\
\text { setuju }\end{array}$ & 9 & 15.25 \\
\hline
\end{tabular}

Berdasarkan Tabel 2 di atas, diketahui bahwa penyebaran kuesioner post-test tersebut diberikan kepada mahasiswa program studi pendidikan jasmani, kesehatan, rekreasi yang berjumlah siswa 59 orang mahasiswa dan jumlah pernyataan sebanyak 10 pada butir kuesioner dalam bentuk tabel dengan instruksi memberikan tanda centang pada kolom yang berbunyi sangat setuju, setuju, kurang setuju, dan tidak setuju. Pengisian kuesioner ini sangat penting untuk mengetahui respons mahasiswa terhadap perangkat pembelajaran/buku ajar yang diajarkan dengan pendekatan pembelajaran berbasis lingkungan. Di samping itu, untuk mengetahui adakah pengaruh pembelajaran berbasis lingkungan yang diterapkan dalam meningkatkan pengetahuan kosakata/ leksikon dalam bahasa mbojo dan inggris serta minat dan percaya diri dalam kegiatan menambah pengetahuan kosakata baru yang berhubungan dengan lingkungan olahraga melalui pembelajaran berbasis lingkungan. 
Pada kuesioner No. 1 mahasiswa yang memilih sangat setuju 30 orang dengan persentase $50.84 \%$, siswa yang memilih setuju 20 orang mahasiswa dengan persentase $33.89 \%$, dan kurang setuju 5 orang mahasiswa dengan persentase $8.47 \%$. Selanjutnya untuk kuesioner 2-15 pembelajaran ini berarti hanya sebagian kecil siswa yang tidak setuju karena belajar bahasa inggris khususnya kosakata/ leksikon menggunakan pembelajaran berbasis lingkungan cukup menyenangkan dan efektif, mahasiswa merasa lebih menguasai tata bahasa Inggris dan menambah penguasaan kosakata, mahasiswa lebih fokus dalam mengikuti pembelajaran bahasa inggris berbasis lingkungan di kelas menumbuhkan minat dan percaya diri mahasiswa pada saat mempelajari kosakata/ leksikon bahasa inggris, indonesia, dan mbojo.

\section{3) Analisis data tes hasil belajar}

Pada tahap pre-test, sebelum menerapkan pembelajaran berbasis lingkungan, pre-test bertujuan untuk mengetahui pemahaman mahasiswa terkait kosakata bahasa inggris. Berdasarkan hasil observasi, kuesioner, dan nilai semester sebelumnya, hasil analisis kuantitatif menunjukkan bahwa mahasiswa yang memperoleh nilai 80 lima orang, mahasiswa yang memperoleh nilai 75 lima orang, mahasiswa yang memperoleh nilai 70 lima orang, mahasiswa yang memperoleh nilai 65 dua puluh orang, dan mahasiswa yang memperoleh nilai 50 dua empat orang. Mahasiswa yang memenuhi nilai KKM hanya 15 orang, sedangkan 44 mahasiswa lainnya belum memenuhi nilai KKM yang ditentukan program studi bahasa inggris adalah 70 . Dari hasil kualitatif membuktikan bahwa mahasiswa memiliki permasalahan yang serupa yaitu pemahaman terhadap pengua-saan kosakata bahasa inggris.

Dari hasil analisis data kualitatif, diketahui bahwa pengembangan kreativitas mahasiswa dalam penguasaan kosakata bahasa inggris setelah penerapan pembelajaran berbasis lingkungan mengalami peningkatan pada tahap post-test. Peningkatan hasil data kualitatif tersebut didukung pula oleh peningkatan hasil data kuantitatif yang berupa hasil tes mahasiswa dalam penguasaan kosakata bahasa inggris yang dilakukan pada akhir pembelajaran (post-test). Berdasarkan hasil analisis kuantitatif post- test dari 59 mahasiswa, terdapat 54 orang mahasiswa yang telah mencapai KKM sedangkan 5 orang mahasiswa yang belum mencapai KKM. Secara umum, para mahasiswa telah mengalami perkembangan dalam penguasaan kosakata/ leksikon bahasa inggris. Dapat disimpulkan bahwa pembelajaran lingkungan memiliki pengaruh yang posistif terhadap pengembangan kreativitas mahasiswa dan hasil belajar mahasiswa pada penguasaan kosakata/ leksikon dan bahasa Inggris.

\section{SIMPULAN DAN SARAN}

\section{A. Simpulan}

Berdasarkan hasil penelitian pengembangan perangkat pembelajaran bahasa inggris berbasis lingkungan (leksikon dalam bahasa mbojo) dapat mengembangkan kreativitas mahasiswa dan hasil belajar mahasiswa pada mata pelajaran bahasa inggris pada program studi pendidikan, jasmani, kesehatan dan rekreasi tahun akademik 2020/2021. Pengembangan perangkat pembelajaran (buku ajar) bahasa inggris berbasis lingkungan dinyatakan layak untuk digunakan pada perkuliahan bahasa inggris karena disusun sesuai dengan standar penulisan bahan ajar, materi yang disajikan dengan baik, bahasa yang digunakan mudah untuk dipahami, soal yang diberikan dapat dikerjakan oleh mahasiswa. Buku ajar juga efektif dalam meningkatkan pencapaian hasil belajar mahasiswa karena terlibat secara aktif dalam menemukan materi, menemukan hubungan antara materi, mampu menerapkan pengetahuannya sehingga mahasiswa akan mampu mengkonstruksi pengetahuan yang diperoleh dari pengalamannya dan dapat meningkatkan dan mengembangkan kreativitas mahasiswa.

\section{B. Saran}

Adapun saran yang dapat disampaikan berdasarkan hasil penelitian pengembangan ini, yaitu: (1) mata kuliah bahasa inggris dalam melaksanakan proses pembelajaran dapat menerapkan pembelajaran berbasis lingkungan dapat mengembangkan kreativitas penguasaan kosakata/leksikon mahasiswa, (2) Diharapkan kepada dosen-dosen mata kuliah lain juga dapat menerapkan metode ini sehingga dapat mengembangkan kreativitas dan hasil belajar mahasiswa, (3) bagi pihak universitas, sosialisasi penggunaan 
pembelajaran berbasis lingkungan perlu di laksanakan guna dapat di terapkan di sekolah oleh semua guru mata pelajaran.

\section{DAFTAR RUJUKAN}

Afrianti, I. (2017). Pembelajaran Berbasis Lingkungan Dalam Meningkatkan Keterampilan Menulis Karangan Deskriptif Bahasa Inggris Siswa Kelas VII Smp Islam Nurul Ihsan Kota Bima.

Arikunto, Suharsini. 2005. Prosedur penelitian suatu pendekatan praktek. Jakarta: PT Rineka Cipta.

Asmedy. (2018). Pengembangan Perangkat Pembelajaran Bangun Datar dengan Pendekatan Open Ended. 1, 66-72. jiipstkipyapisdompu.ac.id.

Bang, Anna, and Bundsgaard. 2012. Communicative Competences and Language Learning in an Ecological Perspective: The Triple Contexts of Participation and Language Learning from Childhood to Adulthood. Denmark Aarhus University and University of southern Denmark.

Endah Nur Tjendani DKK. 2020. Linguistic Terapan dalam Berbagai Perperktive. Jalan Sari Dana IV No.1 Denpasar. Penerbit Yaguwipa. Denpasar.

Endah Nur Tjendani Dkk. 2019. An Ecolinguistics Perspective for English Syllabus
Development. E-ISSN: 2442-7586 P-ISSN: 2541-5514. E-Journal of Linguistics.

Halliday, M.A.K. \& Matthiessen, C.M.I.M. (2014). An introduction to Functional Grammar. 4th.ed.London, Arnold.

Kridalaksana, Harimurti. 1984. Kamus Linguistik. Jakarta: Gramedia Pustaka.

Maria Arina Luardini DKK. 2018. Ecolinguistics for teaching English. Advances in Social Science, Education and Humanities Research, volume 262. Antlantis press.

Richard, Jack C and Rodgers, Theodore S. 2003.Approach and Method in Language Teaching.New York: Cambridge University Press.

Rhodes.m.1961. An Analysis Of Creatifity. The phi delta kappan. 42(7) 305-310.

Sariyati, I. (2011). Efektivitas Penggunaan Metode Total Physical Response dalam Meningkatkan Penguasaan Vocabulary Bahasa Inggris pada Siswa Sekolah Dasar. Jurnal Pendidikan Universitas Garut, 11(01), 38-49.

Wulan, G. (2007). Leksikon. Journal of Experimental Psychology: General, 136(1), 23-42.

Syukri Hamzah. 2013. Pendidikan Lingkungan. Bandung: PT Refika Aditama. 